\title{
Hemodynamic Effects of Ventricular Defibrillation
}

\author{
Donald G. Pansegrau and François M. Abboud \\ From the Cardiovascular Research Laboratories, Department of Medicine, \\ University of Iowa, College of Medicine, Iowa City, Iowa 52240
}

A B S T R A C T Hemodynamic responses to ventricular defibrillation were studied in anesthetized dogs. Observations were made on arterial, right atrial and left ventricular end-diastolic pressures, on cardiac output (dye dilution), heart rate, and right atrial electrocardiogram. Ventricular fibrillation was induced electrically with a bipolar electrode catheter placed in the right ventricle. Fibrillation was maintained for 15 or $30 \mathrm{sec}$ and terminated with a $400 \mathrm{w}$ sec capacitor discharge across the thoracic cage.

Responses lasted 1-10 min after conversion and included a cholinergic and an adrenergic component. The cholinergic component was characterized by sinus bradycardia, periods of sinus arrest, atrioventricular block, and ventricular premature beats. The adrenergic component included increases in arterial pressure, in cardiac output, and in left ventricular stroke work at a time when left ventricular end-diastolic pressure was normal; there was no change in total peripheral resistance. The $\mathrm{pH}$ of arterial blood decreased slightly and $\mathrm{pCO}_{2}$ increased but $\mathrm{pO}_{2}$ and the concentration of lactate were unchanged. Bilateral vagotomy and intravenous administration of atropine blocked the cholinergic component, unmasked a sinus tachycardia, and accentuated the adrenergic component of the response. The latter was blocked by intravenous administration of propranolol and phenoxybenzamine.

These responses were related primarily to conversion of ventricular fibrillation rather than to the electrical discharge of countershock because countershock without ventricular fibrillation caused more transient and smaller responses than those observed with defibrillation: furthermore, the hemodynamic effects of defibrillation were augmented by prolongation of the duration of

This work was presented in part at the 41 st Annual Meeting of the Central Society for Clinical Research, Chicago, 1 November 1968. Preliminary reports have appeared in abstract form $(1,2)$.

Dr. Pansegrau's present address is Carswell Air Force Base, Fort Worth, Tex.

Received for publication 1 August 1969 and in revised form 4 September 1969. fibrillation. The results suggest that the cholinergic component of the response may be detrimental in that it favors spontaneous recurrence of fibrillation; on the other hand, the adrenergic component may be essential for conversion since only one of six dogs depleted of endogenous catecholamines with reserpine survived ventricular defibrillation.

\section{INTRODUCTION}

The use of the cardiac monitor has resulted in prompt recognition and early treatment of ventricular fibrillation with increasing frequency in the past decade. Nonetheless, mortality from this cardiovascular catastrophe remains high. Information concerning the hemodynamic responses associated with ventricular defibrillation is lacking.

Previous studies have dealt primarily with cardiac effects of electrical stimulation and of alternating current (AC) and direct current (DC) countershocks without ventricular fibrillation (3-13). Such observations were made on isolated hearts $(3,4)$, on atrial muscle $(5,6)$, or on ventricular muscle (7-9) and indicate that electrical stimulation may activate intracardiac sympathetic as well as parasympathetic fibers. Childers, Rothbaum, and Arnsdorf (10) described significant but transient effects of internal DC shock on the electrical properties of the heart; these included delay in atrioventricular transmission, shortening of atrial and ventricular refractory periods, and increased ventricular excitability. Cobb, Wallace, and Wagner reported brief periods of sinus bradycardia and increased myocardial contractile force after AC or DC countershock (4). Capapas and Martin (11) reported small increases in arterial pressure and heart rate after DC shock across the closed chest of dogs. Lown, Kleiger, and Williams (12) and Ten Eick, Wyte, Ross, and Hoffman (13) emphasized the interaction between digitalis and the increased ventricular irritability after countershock.

In other studies $(14,15)$ ventricular fibrillation was induced and the effectiveness of DC shock in converting 
this arrhythmia was compared to that of AC shock. The superiority of the DC current for ventricular defibrillation was demonstrated.

The experiments described in this report were done to obtain information on the hemodynamic changes associated with ventricular defibrillation. Differences between the transient effect of DC countershock administered without fibrillation and the more sustained response to defibrillation were recognized. The contributions of a cholinergic and an adrenergic component to the response were assessed and the influence of each component on the success of defibrillation was evaluated.

\section{METHODS}

Male mongrel dogs weighing 14-24 kg were anesthetized with chloralose, $500 \mathrm{mg} / \mathrm{kg}$, and urethane, $50 \mathrm{mg} / \mathrm{kg}$. Decamethonium bromide, $0.3 \mathrm{mg} / \mathrm{kg}$, was given intravenously and additional doses were given when necessary to maintain muscular relaxation. ${ }^{1}$ The dogs were ventilated artificially with a mixture of oxygen and air ${ }^{2}$ through a cuffed endotracheal tube connected to a respiratory pump. Heparin (Liquaemin Sodium “10"), $500 \mathrm{U} / \mathrm{kg}$, was injected intravenously. Catheters were placed in the right atrium, left ventricle, and aorta and connected to transducers (Statham Instruments, Inc., Los Angeles, Calif.) for measurement of right atrial, left ventricular end-diastolic, and aortic pressures. ${ }^{3}$ Cardiac output was measured by injecting Indocyanine Green dye through a catheter placed in the pulmonary artery and by withdrawing blood through a catheter placed in the abdominal aorta and connected to the cuvette of a densitometer (Gilford Instrument Company, Elyria, Ohio). The electrocardiogram was monitored continuously. All measurements were recorded with a direct-writing oscillograph (Sanborn Co., Waltham, Mass.). Arterial blood samples were obtained at regular intervals throughout the experiment for measurements of $\mathrm{pH}, \mathrm{pO}_{2}, \mathrm{pCO}_{2}$ (Instrumentation Laboratory, Inc., Watertown, Mass.) and the concentration of lactate (16). Ventricular fibrillation was induced by delivering a current of $5 \mathrm{v}$ and 60 pulses/sec for periods of 1-2 sec to the right ventricle using an $S_{4}$ (Grass Instrument Co., Quincy, Mass.) stimulator and a bipolar electrode catheter." Attempts were made to terminate the ventricular fibrillation after 15 or $30 \mathrm{sec}$ with a $400 \mathrm{w}$ sec capacitor discharge (Corbin-Farnsworth Inc., Palo Alto, Calif.) delivered with external paddles $10 \mathrm{~cm}$ in diameter placed on each side of the shaved thoracic cage at the level of the heart. Because it was important to maintain fibrillation for

\footnotetext{
${ }^{1}$ Decamethonium bromide was given to produce relaxation of respiratory muscles and to permit adequate ventilation. It reduced the vigorous muscular contractions associated with the high level of electrical countershock used in these animals. The doses used were too small to cause ganglionic blockade or release of histamine.

${ }^{2}$ The mixture of approximately $30 \%$ oxygen in air was sufficient to maintain arterial $\mathrm{pO}_{2}$ above $100 \mathrm{~mm} \mathrm{Hg}$.

${ }^{3}$ The frequency response of the left ventricular and aortic recording systems was flat to 12.5 and $10 \mathrm{cycles} / \mathrm{sec}$ respectively. Small volume displacement transducers $\left(0.04 \mathrm{~mm}^{3} / 100\right.$ $\mathrm{mm} \mathrm{Hg})$ were used $(\mathrm{P} 23 \mathrm{Db})$.

"The current estimated from measurements of the resistance of the bipolar electrode catheter placed in the right ventricle in four experiments approximated 10-40 ma.
}

specific periods of time the high level of electrical energy of $400 \mathrm{w}$ sec was used uniformly to ascertain immediate conversion; nevertheless, in several experiments, particularly when ventricular fibrillation was maintained for periods of $30 \mathrm{sec}$, conversion was not achieved with a single countershock and one or two additional discharges were necessary.

Observations were made before and at frequent intervals after defibrillation for a period of $15 \mathrm{~min}$. During this period the hemodynamic measurements, blood gases, and $\mathrm{pH}$ would have returned to control levels. In four dogs repeated episodes of fibrillation followed by defibrillation were carried for a period of $1 \frac{1}{2} \mathrm{hr}$. The changes in heart rate and arterial pressure with each defibrillation were reproducible.

Responses observed after defibrillation included marked bradycardia associated with an increase in cardiac output and a rise in arterial pressure suggesting activation of the two major components of the autonomic system: the parasympathetic-cholinergic component and the sympatheticadrenergic component. In an attempt to block the first component we sectioned both vagi and administered atropine sulfate $0.2 \mathrm{mg} / \mathrm{kg}$ intravenously. These interventions will be referred to as causing a "cholinergic blockade" but it should be recognized that afferent vagal impulses were also interrupted. After cholinergic blockade, responses to defibrillation included increases in heart rate, cardiac output. and arterial pressure which suggested a possible activation of beta adrenergic receptors. After obtaining the responses to defibrillation in six dogs that had atropine and bilateral vagotomy, propranolol (Inderal) was injected intravenously in a dose of $0.5 \mathrm{mg} / \mathrm{kg}$. This dose was sufficient to antagonize increases in cardiac output and in heart rate caused by the intravenous infusion of isoproterenol in doses of $0.125,0.25$, and $0.5 \mu \mathrm{g} / \mathrm{kg}$ per min over a period of 3-5 min. The magnitude of the changes in cardiac output and heart rate occurring during the infusions of isoproterenol was similar to that observed after conversion from episodes of fibrillation lasting 15 or $30 \mathrm{sec}$.

The administration of the beta blockers did not antagonize completely the pressor responses to defibrillation; therefore, five dogs that had cholinergic blockade were given the alpha adrenergic receptor blocker phenoxybenzamine $(0.5 \mathrm{mg} / \mathrm{kg})$ (Dibenzyline) intravenously. Responses to defibrillation were tested before and after the blocker. The dose of phenoxybenzamine was sufficient to block pressor responses to intravenous norepinephrine bitartrate $(0.3,0.6$, and $1.2 \mu \mathrm{g} / \mathrm{kg}$ per min) administered to two of the five dogs.

In another group of six dogs reserpine was administered intraperitoneally in a dose of $0.25 \mathrm{mg} / \mathrm{kg}$ per day on 2 successive days. On the 3 rd day, responses to defibrillation were tested after the animals had had atropine $(0.2 \mathrm{mg} / \mathrm{kg})$ and bilateral vagotomy. A $15 \mathrm{sec}$ period of fibrillation was induced first and if the dog survived that episode a $30 \mathrm{sec}$ period of fibrillation was induced after hemodynamic values had returned to control levels, or $30 \mathrm{~min}$ after the first episode.

Pressures were recorded continuously. Mean systemic arterial pressure was obtained by electrical integration of the aortic pressure pulse. Cardiac output was measured before and at 1,5 , and $15 \mathrm{~min}$ after defibrillation. Occasionally, it was necessary to reject the dye dilution curve because of arrhythmias at the time of the measurement. The cardiac output was calculated using the Hamilton-Stewart equations (17) and expressed as cardiac index in milliliters per minute per kilogram body weight. Heart rate was obtained from the aortic pressure tracing. Left ventricular stroke work was calculated as the product of stroke volume in milliliters per beat and mean arterial pressure minus mean right atrial 
TABLE I

Hemodynamic Data Obtained before Ventricular Fibrillation (B) and at Various Intervals after $(A)$

Conversion from Episodes of Fibrillation Lasting 30-36 sec

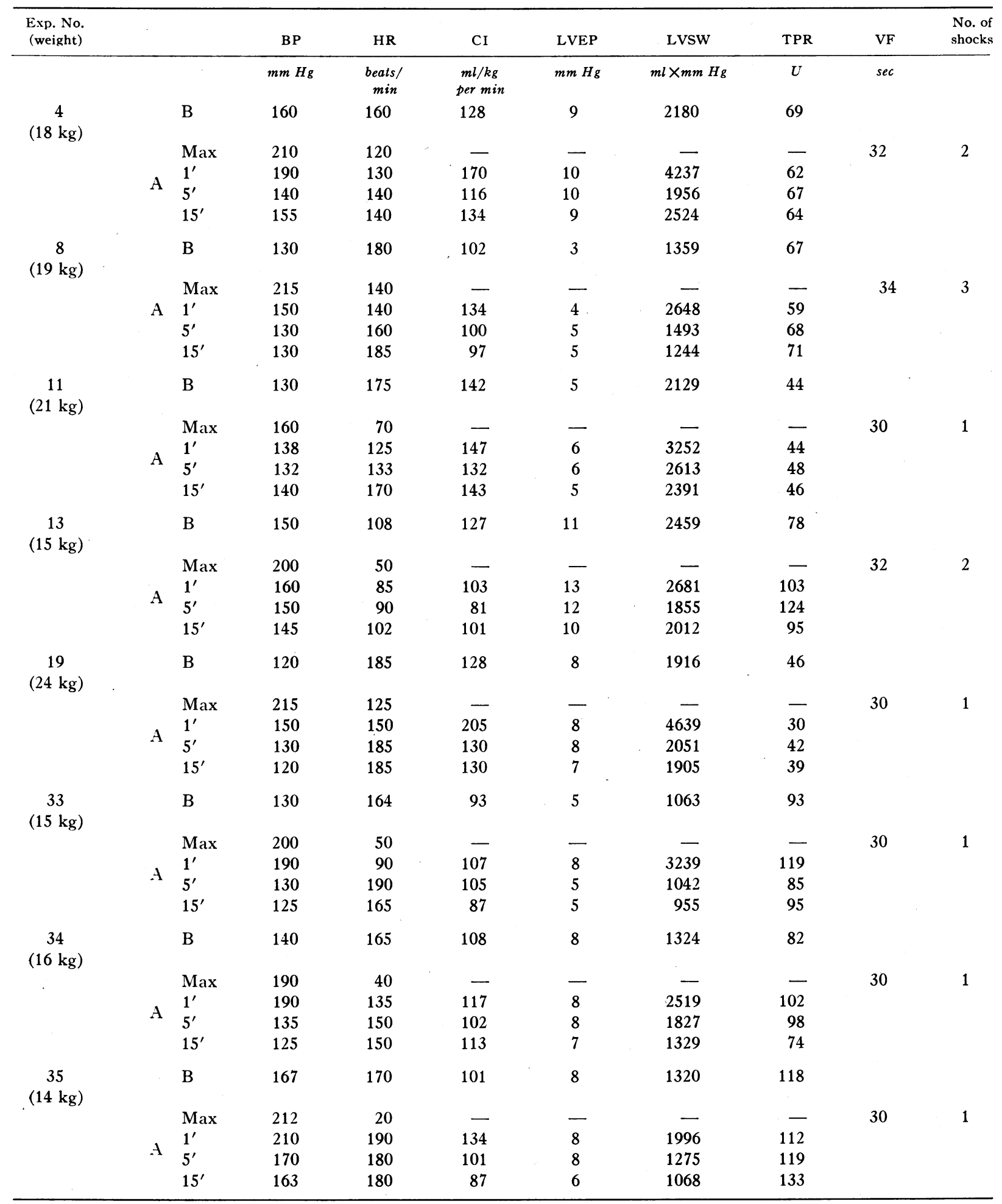


TABLE I-(Continued)

\begin{tabular}{|c|c|c|c|c|c|c|c|c|c|c|}
\hline $\begin{array}{l}\text { Exp. No. } \\
\text { (weight) }\end{array}$ & & & BP & HR & CI & LVEP & LVSW & TPR & VF & $\begin{array}{l}\text { No. of } \\
\text { shocks }\end{array}$ \\
\hline \multirow{6}{*}{$\begin{array}{c}39 \\
(17 \mathrm{~kg})\end{array}$} & & & $m m \mathrm{Hg}$ & $\begin{array}{l}\text { beats/ } \\
\text { min }\end{array}$ & $\begin{array}{c}\mathrm{ml} / \mathrm{kg} \\
\operatorname{per} \mathrm{min}\end{array}$ & $m m \mathrm{Hg}$ & $m l \times m m ~ H g$ & $U$ & sec & \\
\hline & & B & 145 & 160 & 163 & 5 & 2520 & 51 & & \\
\hline & & Max & 180 & 40 & - & - & - & - & 36 & 2 \\
\hline & \multirow{3}{*}{$\mathrm{A}$} & $1^{\prime}$ & 170 & 190 & 231 & 4 & 3537 & 42 & & \\
\hline & & $5^{\prime}$ & 145 & 115 & 149 & 6 & 3146 & 56 & & \\
\hline & & $15^{\prime}$ & 140 & 190 & 173 & 4 & 2161 & 46 & & \\
\hline \multirow{10}{*}{$\begin{array}{l}\text { Means and } \\
\text { standard } \\
\text { errors }\end{array}$} & \multirow[b]{4}{*}{ ' } & B & 141 & 163 & 121 & 6.9 & 1808 & 72 & & \\
\hline & & & 4.9 & 7.0 & 7.1 & 0.8 & 172.6 & 7.6 & & \\
\hline & & Max & $198^{*}$ & $73^{*}$ & 一 & - & - & - & 31.5 & 1.6 \\
\hline & & & 5.8 & 13.8 & - & - & - & - & & \\
\hline & \multirow{6}{*}{$\mathrm{A}$} & $1^{\prime}$ & $172^{*}$ & $137^{*}$ & $150^{*}$ & 7.7 & $3194^{*}$ & 75 & & \\
\hline & & & 7.6 & 11.6 & 13.9 & 0.9 & 266.5 & 10.7 & & \\
\hline & & $5^{\prime}$ & 140 & $149^{*}$ & 113 & 7.6 & 1918 & 79 & & \\
\hline & & & 4.2 & 10.6 & 6.6 & 0.7 & 204.4 & 9.4 & & \\
\hline & & $15^{\prime}$ & 138 & 163 & 118 & 6.4 & 1732 & 74 & & \\
\hline & & & 4.6 & 8.9 & 9.1 & 0.6 & 185.9 & 9.4 & & \\
\hline
\end{tabular}

Entries represent values of mean arterial blood pressure (BP), heart rate $(\mathrm{H})$, cardiac index $(\mathrm{CI})$, left ventricular end-diastolic pressure (LVEP), left ventricular stroke work (LVSW), and total peripheral resistance (TPR). The duration of ventricular fibrillation is entered under VF in seconds and the number of countershocks necessary for conversion is shown in the last column. Observations made after conversion were obtained at the time of the maximal response (Max) which occurred usually within $45 \mathrm{sec}$ and at $1 \mathrm{~min}\left(1^{\prime}\right), 5 \mathrm{~min}\left(5^{\prime}\right)$, and $15 \mathrm{~min}\left(15^{\prime}\right)$ after conversion. Maximal responses are indicated for BP and HR only because the first cardiac output obtained after conversion was measured after the maximal responses for BP and $H R$ had been reached. Right atrial pressure averaged $2.9 \pm \mathrm{SE} 0.6 \mathrm{~mm} \mathrm{Hg}$ before fibrillation and $3.7 \pm 1.0,3.2 \pm 0.8$, and $2.8 \pm 0.5 \mathrm{~mm} \mathrm{Hg}$ at $1^{\prime}, 5^{\prime}$, and $15^{\prime}$ after defibrillation respectively. Heart rates shown in this and in subsequent tables were obtained from aortic pressure pulses.

* Indicates that average values observed after defibrillation were significantly different from corresponding values obtained before fibrillation.

pressure and expressed in milliliters $\times \mathrm{mm} \mathrm{Hg}$. Total systemic resistance was calculated as the quotient of mean arterial pressure over cardiac output in liters per minute and expressed in arbitrary units.

Paired comparisons were made using the paired $t$ test or Wilcoxon's signed-ranks test (18) and group comparisons were made with the unpaired $t$ test. Differences were considered significant at a $P$ value $<0.05$.

\section{RESULTS}

Effects of ventricular defibrillation (group 1). Hemodynamic responses were observed in a group of nine dogs (Table I). After $30 \mathrm{sec}$ of fibrillation a single electrical countershock was sufficient to induce and maintain conversion in five of the nine dogs; in the other four spontaneous recurrence of fibrillation necessitated one or two additional electrical countershocks for conversion (Fig. 1).

The restoration of sinus rhythm was characterized by sinus bradycardia which was maximal during a period of $20 \mathrm{sec}$ immediately after defibrillation. Periods of sinus node arrest, suggested by the presence of atrial asystoles lasting $2 \mathrm{sec}$ or longer, occurred after $71 \%$ of the episodes of fibrillation (Fig. 2).

Blood pressure increased gradually to levels higher than control (Figs. 1 and 3). Cardiac output measured at $1 \mathrm{~min}$ after defibrillation was increased and the calculated left ventricular stroke work was augmented; left ventricular end-diastolic pressure had returned to control levels. Total peripheral resistance did not change significantly. Both the pressor and cardiac output responses were terminated within $5 \mathrm{~min}$ after conversion, but the bradycardia persisted for 5-10 min (Fig. 3).

Effect of cholinergic blockade on responses to ventricular defibrillation (group 2). The effects of defibrillation were studied in a group of 10 dogs after section of both vagi and administration of $0.2 \mathrm{mg} / \mathrm{kg}$ of atropine intravenously (Table II and Fig. 4). These interventions prevented the marked and sustained bradycardia that was seen after conversion in group 1 ; instead a brief period of bradycardia lasting only $5-15$ 


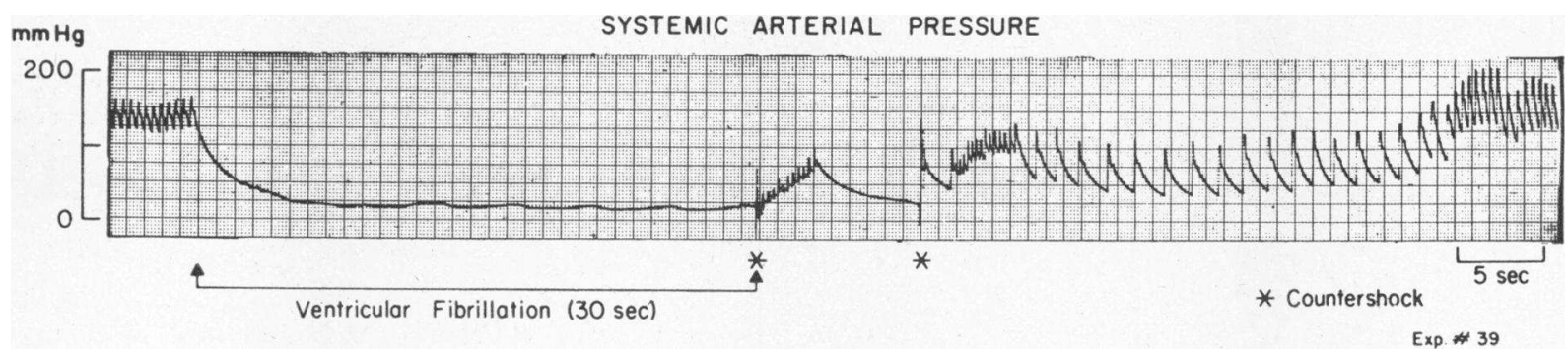

FIGURE 1 Ventricular fibrillation recurred spontaneously requiring a second $400 \mathrm{w}$ sec capacitor discharge after temporary conversion with the first countershock. Restoration of sinus rhythm was characterized by marked bradycardia before the return of blood pressure to control levels. The hypertensive phase was delayed for at least $20 \mathrm{sec}$.

sec (Fig. 5) was followed by an increase in heart rate to levels higher than control. The tachycardia reached a peak at $10-20 \mathrm{sec}$ and was terminated between 1 and 5 min after conversion. Increases in cardiac output, arterial pressure, and left ventricular stroke work were evident after conversion as in the first group of dogs. Left ventricular end-diastolic pressure measured at that time had returned to control levels. There were no significant changes in total peripheral resistance.

In assessing the effects of cholinergic blockade by comparing results in group 1 vs. group 2 an "unpaired" statistical analysis was carried out; the variations from dog to dog obscured the statistical significance of the effects that cholinergic blockade might have had on the pressor and cardiac output responses to defibrillation (Table II). Therefore, responses to defibrillation were measured in another group of seven dogs both before and after atropine and vagotomy in the same animal and "paired" comparisons of responses were possible.
Episodes of fibrillation lasted either $15 \mathrm{sec}$ (two dogs) or $30 \mathrm{sec}$ (five dogs). Increases in arterial blood pressure $(+14 \pm \mathrm{sE} 9.7 \mathrm{~mm} \mathrm{Hg})$, in cardiac index $(+10$ $\pm 12 \mathrm{ml} / \mathrm{kg}$ per $\mathrm{min})$, and stroke work $(+753 \pm 224 \mathrm{ml}$ $\times \mathrm{mm} \mathrm{Hg})$ measured at $1 \mathrm{~min}$ after conversion were greater $(+34.7 \pm 12.4 \mathrm{~mm} \mathrm{Hg} ;+39.1 \pm 11.8 \mathrm{ml} / \mathrm{kg}$ per min; and $+999 \pm 196 \mathrm{ml} \times \mathrm{mm} \mathrm{Hg}$, respectively) after atropine and vagotomy $(P<0.05)$.

In another group of six dogs, the right atrial electrocardiogram and arterial pressure were recorded. 15and 30 -sec periods of ventricular fibrillation were induced. Results obtained during the first $10 \mathrm{sec}$ after conversion are in Fig. 5 and demonstrate the effectiveness of cholinergic blockade in abolishing the sinus bradycardia. A prolongat on of the PR interval and intermittent failure of atrioventricular conduction were still apparent during the first 5-15 sec (Fig. 5) after which a tachycardia became the major response (Table II). Before cholinergic blockade the frequency of premature

RIGHT ATRIAL EKG BEFORE ATROPINE AND VAGOTOMY
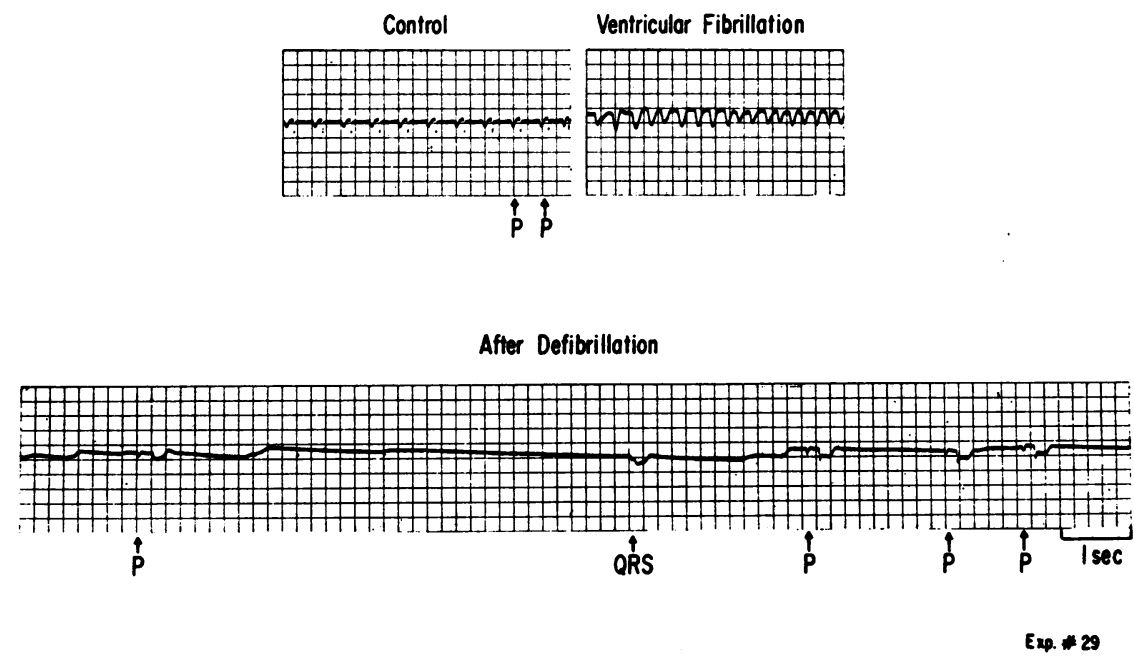

Figure 2 Sinus arrest, A-V block, and nodal or ventricular beats were seen frequently before cholinergic blockade. 
ventricular contractions averaged $8.4 \pm$ SE 2.3 during the first $20 \mathrm{sec}$ period and $12.1 \pm 1.8$ during the 1st minute after defibrillation; after cholinergic blockade the incidence of premataure beats fell to $1.8 \pm 0.5$ and 2.7 \pm 0.6 during corresponding intervals.

Spontaneous recurrence of ventricular fibrillation was not infrequent during the period immediately after defibrillation (Fig. 1). This susceptibility was minimized by cholinergic blockade. The number of countershocks necessary to maintain conversion was reduced significantly after the blockade (Table III).

Effect of duration of ventricular fibrillation on the hemodynamic responses (Table IV). When the duration of ventricular fibrillation was prolonged, the maximal increases in arterial pressure, the time to reach the peak pressor response, and the duration of the pressor response were all augmented. Increases in cardiac index and in left ventricular stroke work were augmented also. The reduction in heart rate before cholinergic blockade was related to the duration of fibrillation; the tachycardia observed after cholinergic blockade lasted longer when the period of fibrillation was prolonged (Table IV). Electrocardiographic observations made on atrial and ventricular rates and on the PR interval within $10 \mathrm{sec}$ after defibrillation indicate an effect of the duration of fibrillation both before and after cholinergic blockade (Fig. 5).

Levels of $p O s, p C O s, p H$, and lactate in arterial blood $($ Table $V$ ). There was a minimal reduction in $\mathrm{pH}$ and a small elevation in $\mathrm{pCO}_{2} 1$ min after conversion from ventricular fibrillation at a time when the hemodynamic responses were pronounced. These changes in $\mathrm{pH}$ and $\mathrm{pCO}_{2}$ were transient; $\mathrm{pO}_{2}$ and the concentration of lactate were unchanged.
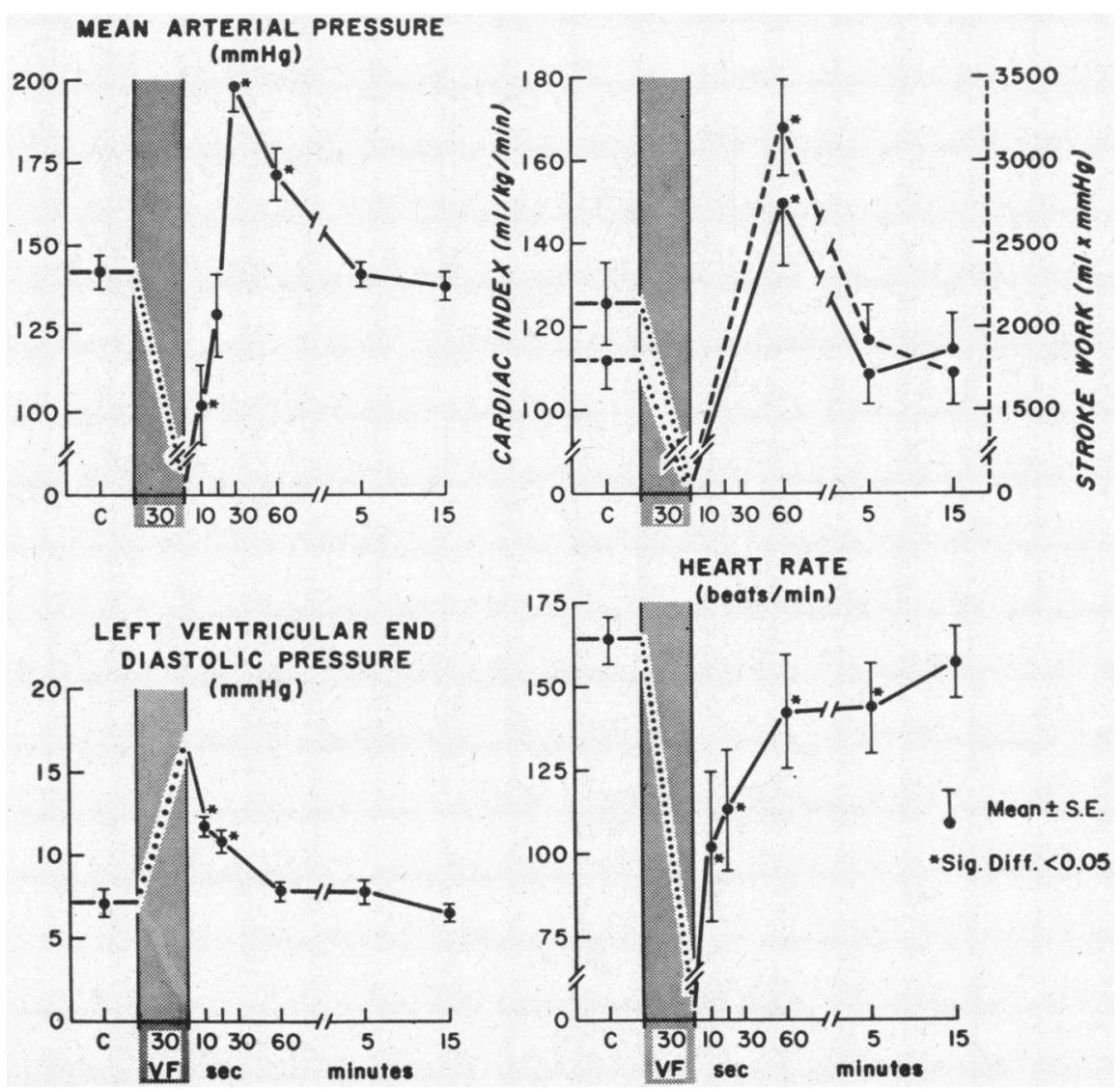

FIGURE 3 Averages and standard errors (nine dogs) of values observed before (C) and at various intervals $(10,20,30,60, \mathrm{sec} ; 5$ and $15 \mathrm{~min})$ after conversion from episodes of fibrillation (VF) lasting approximately $30 \mathrm{sec}$ as indicated by the shaded area. The animals had intact vagi and had had no atropine. Heart rate was obtained from aortic pressure pulses; bradycardia was present when systemic arterial pressure was still below control levels. The changes in right atrial pressure paralleled those of left ventricular end-diastolic pressure. The asterisks indicate that the values were significantly different from (C). 
TABLE II

Hemodynamic Data Obtained before $(B)$ and at Various Intervals after $(A)$ Conversion from Episodes of Ventricular Fibrillation Lasting 30-36 sec in Dogs That Had Bilateral Vagotomy and Atropine

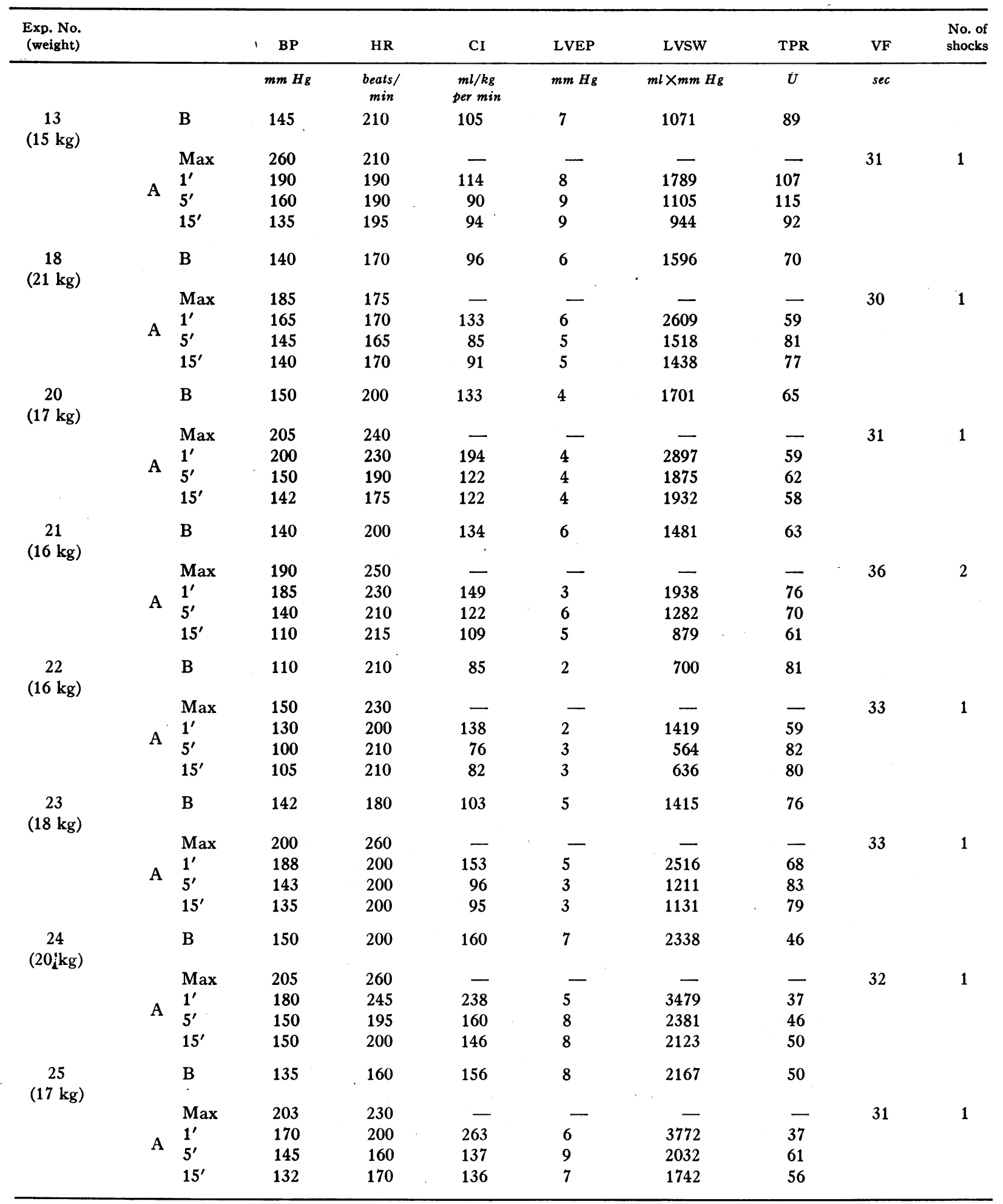


TABLE II-(Continued)

\begin{tabular}{|c|c|c|c|c|c|c|c|c|c|c|}
\hline $\begin{array}{l}\text { Exp. No. } \\
\text { (wwight) }\end{array}$ & & & BP & HR & CI & LVEP & LVSW & TPR & VF & $\begin{array}{l}\text { No. of } \\
\text { shocks }\end{array}$ \\
\hline & & & $m m \mathrm{Hg}$ & $\begin{array}{c}\text { beats/ } \\
\min \end{array}$ & $\begin{array}{c}\mathrm{ml} / \mathrm{kg} \\
\text { per min }\end{array}$ & $m m \mathrm{Hg}$ & $m l \times m m H g$ & $U$ & $\mathrm{sec}$ & \\
\hline \multirow{5}{*}{$\begin{array}{c}39 \\
(17 \mathrm{~kg})\end{array}$} & & B & 142 & 150 & 133 & 5 & 2138 & 61 & & \\
\hline & & $\operatorname{Max}$ & 195 & 215 & - & - & - & - & 30 & 1 \\
\hline & ( & $1^{\prime}$ & 164 & 180 & 226 & 4 & 3529 & 42 & & \\
\hline & A & $5^{\prime}$ & 140 & 160 & 137 & 5 & 2020 & 58 & & \\
\hline & & $15^{\prime}$ & 136 & 150 & 110 & 5 & 1678 & 71 & & \\
\hline \multirow{5}{*}{$\begin{array}{c}41 \\
(19 \mathrm{~kg})\end{array}$} & & B & 155 & 145 & 128 & 6 & 2570 & 62 & & \\
\hline & & $\operatorname{Max}$ & 185 & 220 & - & - & - & - & 35 & 2 \\
\hline & & $1^{\prime}$ & 175 & 180 & 182 & 4 & 3367 & 49 & & \\
\hline & A & $5^{\prime}$ & 150 & 170 & 160 & 5 & 2662 & 48 & & \\
\hline & & $15^{\prime}$ & 145 & 150 & 95 & 5 & 1928 & 70 & & \\
\hline \multirow{10}{*}{$\begin{array}{l}\text { Means and } \\
\text { standard } \\
\text { errors }\end{array}$} & & B & 140 & 183 & 123 & 5.8 & 1718 & 66 & & \\
\hline & & & 3.7 & 7.5 & 7.6 & 0.5 & 176.2 & 4.0 & & \\
\hline & & $\operatorname{Max}$ & $202^{*}$ & $229^{*} \ddagger$ & - & - & - & - & 32.2 & 1.2 \\
\hline & & & 8.3 & 7.8 & - & - & - & - & & \\
\hline & & $1^{\prime}$ & $175^{*}$ & $203^{*} \ddagger$ & $179^{*}$ & $5.2 \ddagger$ & $2731^{*}$ & 59 & & \\
\hline & & & 5.8 & 7.5 & 15.0 & 0.5 & 245.2 & 6.4 & & \\
\hline & A & $5^{\prime}$ & 142 & $185 \ddagger$ & 118 & 5.8 & 1665 & 71 & & \\
\hline & & & 4.8 & 5.9 & 9.2 & 0.7 & 192.7 & 6.2 & & \\
\hline & & $15^{\prime}$ & 133 & 184 & $108^{*}$ & 5.5 & $1443^{*}$ & 69 & & \\
\hline & & & 4.4 & 7.1 & 6.3 & 0.6 & 154.8 & 3.9 & & \\
\hline
\end{tabular}

See footnote to Table I. Values of right atrial pressure averaged $2.8 \pm 0.5,3.2 \pm 0.5,2.8 \pm 0.5$, and $2.7 \pm 0.4 \mathrm{~mm} \mathrm{Hg}$ before and at $1^{\prime}, 5^{\prime}$, and $15^{\prime}$ after conversion respectively.

* Indicates that average values observed after defibrillation were significantly different from corresponding values obtained before fibrillation.

$\ddagger$ Indicates that the average values are significantly different from corresponding values obtained in the group which had no atropine nor vagotomy shown in Table I; the comparisons between the two groups were done using the unpaired $t$ test since the observations were made on different animals in the two groups with the exception of two experiments (Nos. 13 and 39).

Effect of countershock without ventricular fibrillation. The effects of DC shock were smaller or much more transient than corresponding changes observed when the shock was administered after a period of ventricular fibrillation (Table VI). Before cholinergic blockade effects of countershock without fibrillation were small and not statistically significant with the exception of minimal reductions in mean arterial pressure and cardiac output occurring $5 \mathrm{~min}$ after the countershock. After cholinergic blockade there were significant increases in mean arterial pressure and heart rate during the first $10 \mathrm{sec}$ after countershock. These changes were not apparent at $1 \mathrm{~min}$ and there was a small reduction in arterial pressure at $5 \mathrm{~min}$. Cardiac output measured $1 \mathrm{~min}$ after countershock was increased slightly.
Effect of propranolol on responses to ventricular defibrillation in dogs that had atropine and bilateral vagotomy. Propranolol reduced the resting value of arterial blood pressure, cardiac output, and heart rate and antagonized the responses to ventricular defibrillation (Table VII). Increases in heart rate and cardiac output caused by defibrillation were blocked and increases in arterial pressure were reduced significantly but were not abolished. Left ventricular end-diastolic pressure was unchanged by the blocker and its level $1 \mathrm{~min}$ after defibrillation was not different from control. In the same animals increases in cardiac output and heart rate caused by intravenous infusions of isoproterenol were blocked by propranolol.

Effect of phenoxybenzamine on responses to ventricular defibrillation in dogs that had atropine and bilateral 

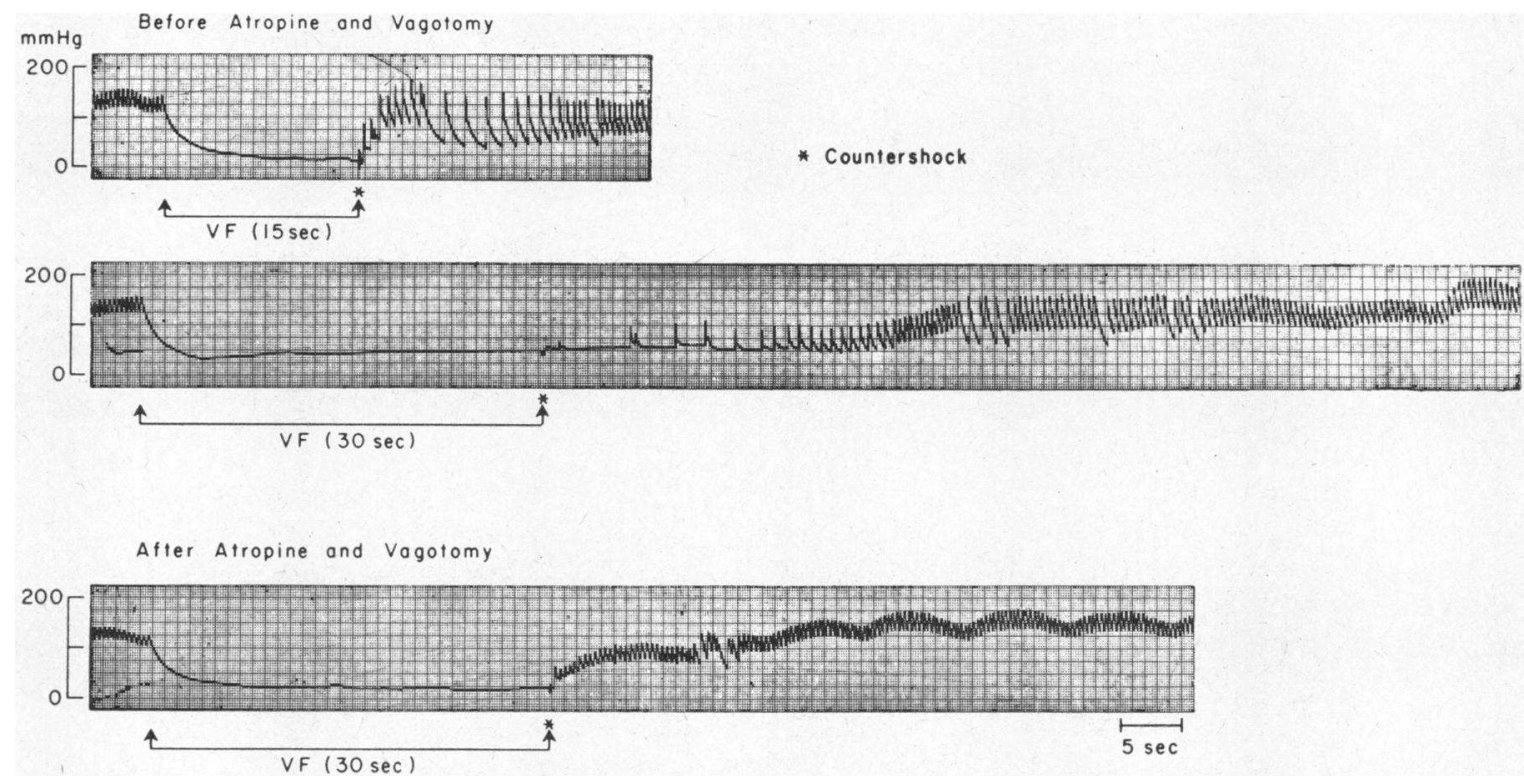

Figure 4 Effect of duration of fibrillation (VF) and of atropine and vagotomy on pressure responses. The bradycardia was accentuated and its duration was prolonged when the period of fibrillation was increased from 15 to $30 \mathrm{sec}$. After cholinergic blockade the period of bradycardia was brief and was followed by tachycardia and the hypertensive phase.

vagotomy. In each of five dogs phenoxybenzamine reduced the resting levels of arterial blood pressure (Table VIII) and of left ventricular end-diastolic pressure significantly; the latter fell from an average of $7.7 \pm \mathrm{SE} 1.2$ to $4.6 \pm 0.3 \mathrm{~mm} \mathrm{Hg}$. Reductions in resting values of cardiac output (Table VIII) and total peripheral resistance $(75 \pm 10.3$ before vs. $61 \pm 15.9 \mathrm{U}$ after the blocker) were not statistically significant. The increase in arterial blood pressure in response to defibrillation was blocked by phenoxybenzamine. The increase in cardiac output measured at 1 min after conversion was reduced by the blocker but the reduction was not statistically significant (Table VIII).

Effect of pretreatment with reserpine on responses to ventricular defibrillation. Only two of six dogs survived conversion from episodes of ventricular fibrillation lasting $15 \mathrm{sec}$ and only one of these two recovered from a $30 \mathrm{sec}$ period of fibrillation. Failure of recovery was associated with two responses which were not present in the untreated animals. Complete atrioventricular heart block, which was transient in untreated dogs, was sustained for 1-2 min in these animals. When atrioventricular conduction was restored, a progressive decline in arterial pressure and cardiac output was observed. In the only dog that recovered from a 30 -sec period of fibrillation transient heart block was followed by a gradual return of arterial pressure and cardiac output to control levels.

\section{DISCUSSION}

The results of this study support two conclusions. The first is that ventricular defibrillation is associated with two major hemodynamic responses; one is a negative chronotropic response which appears to be mediated through a cholinergic mechanism and the other is a positive inotropic response which is related to adrenergic mechanisms.

A second conclusion relates to the contribution of the DC shock per se to these responses. Although DC shock

\section{TABLE III}

Effect of Atropine and Vagotomy on the Number of Countershocks Necessary for Conversion from Ventricular Fibrillation $(V F)$ in a Total of 24 Dogs

\begin{tabular}{|c|c|c|c|c|}
\hline \multirow[b]{2}{*}{ Duration of VF... } & \multicolumn{2}{|c|}{ Untreated dogs } & \multicolumn{2}{|c|}{$\begin{array}{l}\text { Dogs that had } \\
\text { atropine and } \\
\text { vagotomy }\end{array}$} \\
\hline & $15-29 \mathrm{sec}$ & $30-60 \mathrm{sec}$ & $15-29 \mathrm{sec}$ & $30-60 \mathrm{sec}$ \\
\hline $\begin{array}{c}\text { Average No. } \\
\text { of shocks }\end{array}$ & $1.39^{*}$ & $2.30^{*}$ & $1.0 * \ddagger$ & $1.21 * \ddagger$ \\
\hline SE & 0.14 & 0.63 & 0.0 & 0.10 \\
\hline $\mathrm{n}$ & 18 & 10 & 8 & 24 \\
\hline
\end{tabular}

* Indicates that the average values are statistically significant. $\ddagger$ Indicates that the average number of countershocks necessary for conversion after the intravenous administration of atropine and bilateral vagotomy was significantly lower than the corresponding number without these interventions. 
may contribute to the early responses observed within $30 \mathrm{sec}$ after countershock $(4,10)$ the hemodynamic changes which we observed during the period of 1-15 min after defibrillation appear to be related primarily to the episode of fibrillation and to its subsequent conversion.

The negative chronotropic response was manifested by sinus bradycardia and sinus node arrest. Although the period of sinus node arrest occurred within 10-20 sec of ventricular defibrillation, sinus bradycardia was maintained for up to $10 \mathrm{~min}$ after conversion and its magnitude was related to the duration of fibrillation. As-

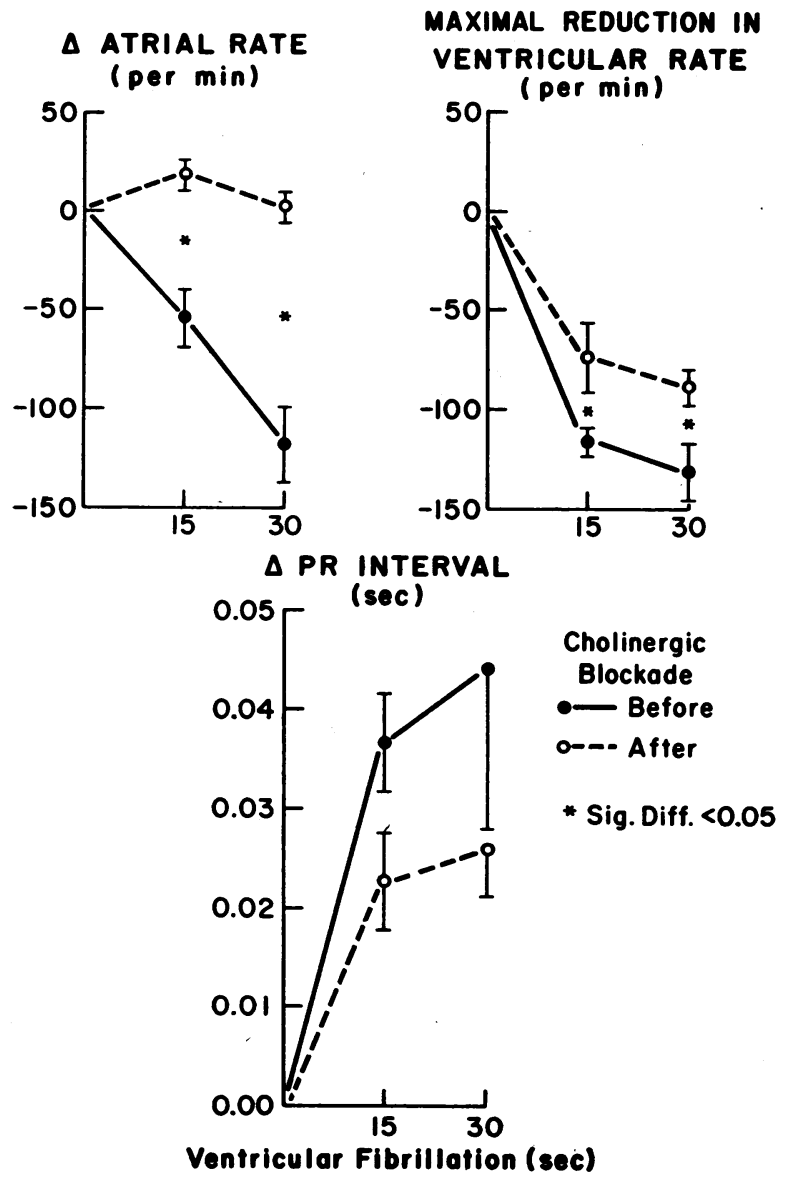

FIGURE 5 Effect of the duration of fibrillation and of cholinergic blockade on changes in atrial and ventricular rate and on the prolongation of the $P R$ interval after defibrillation. The observations made immediately after defibrillation (within the first $10 \mathrm{sec}$ period) were selected for this figure because this is the time at which a bradycardia was still evident when the animals had cholinergic blockade; promptly afterwards, at about $10-20 \mathrm{sec}$ after defibrillation, a sinus tachycardia with a $1: 1$ conduction became evident. The asterisks represent the significance of the difference between observations made before and after cholinergic blockade. sociated with the bradycardia were frequent premature ventricular beats. The administration of atropine and section of the vagi unmasked a sinus tachycardia and reduced or abolished the premature ventricular beats. It is known that the incidence of ectopic beats is a function of the basic ventricular rate (19) and that tachycardia may decrease ventricular irritability. More important than the reduction in the incidence of ectopic beats and possibly related to it was a reduction in the incidence of spontaneous recurrence of ventricular fibrillation from 43 to $13 \%$ by cholinergic blockade. This finding would support the rationale for the use of atropine in the treatment of ventricular fibrillation particularly when fibrillation recurs spontaneously after countershock.

A hypertensive phase sustained over a period of 2-4 min predominated the second component of the response to defibrillation which included also an increase in cardiac output and in stroke work when left ventricular end-diastolic pressure had returned to normal and heart rate was still decreased. These findings indicate a positive inotropic response. The absence of a rise in left ventricular end-diastolic pressure or a significant increase in peripheral resistance would indicate that the contributions of preload or afterload to the cardiac responses were minimal (20). After atropine and vagotomy the inotropic response was more evident and a positive chronotropic response was unmasked. Propranolol antagonized the positive inotropic and chronotropic responses to defibrillation but the rise in arterial pressure, although reduced, was not abolished. The persistence of a pressor response suggested that there was activation of vasoconstrictor alpha adrenergic receptors. Before propranolol there was no change in peripheral resistance in the presence of a significant hypertension; this finding would indicate that there was some increase in peripheral vascular tone without which passive vasodilatation would have occurred in response to the rise in distending pressure. The increase in tone was not sufficient to cause an increase in vascular resistance; but after propranolol a small increase in resistance

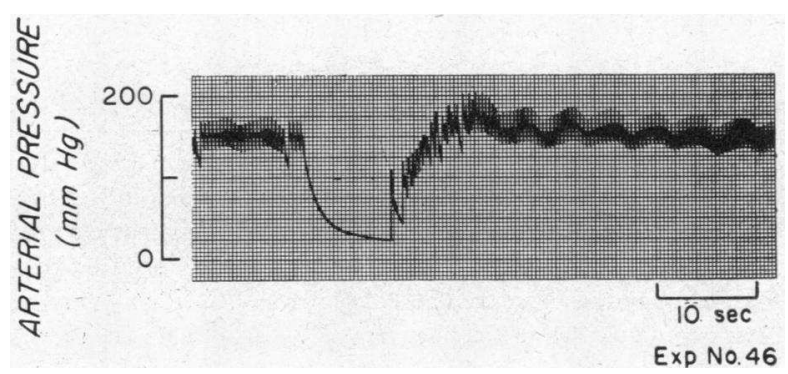

Figure 6 Spontaneous conversion from a brief episode of ventricular fibrillation. A transient bradycardia and an early hypertensive phase were apparent. 
manifested by a rise in arterial pressure without an increase in output (Table VII) became apparent. It is possible that activation of vasodilator beta adrenergic receptors or another vasodilator system as a result of the marked increase in arterial pressure may have masked the vasoconstriction before propranolol.

The administration of phenoxybenzamine abolished the pressor response by preventing the increase in vascular tone and by reducing partly but not consistently the increase in cardiac output. The persistence of an increase in cardiac output without a rise in arterial pressure after phenoxybenzamine (Table VIII) suggests also activation of a vasodilator system.

In an attempt to explain the reason for the reduction in the increase in cardiac output associated with defibrillation after phenoxybenzamine one might suggest that there was a nonspecific depression of cardiac responses by the alpha blocker. A more attractive possi-

TABLE IV

Effect of Duration of Fibrillation (VF) on Responses to Ventricular Defibrillation in Six Untreated Dogs and in Nine Dogs that had Bilateral Vagotomy and Atropine

\begin{tabular}{|c|c|c|c|c|c|c|}
\hline \multirow[b]{2}{*}{ Response } & \multirow[b]{2}{*}{ VF... } & \multicolumn{2}{|c|}{ Untreated dogs $(n=6)$} & \multicolumn{2}{|c|}{$\begin{array}{l}\text { Dogs that had atropine and } \\
\text { vagotomy }(n=9)\end{array}$} & \multirow{2}{*}{$\begin{array}{c}\text { Comparison of } \\
\text { responses at } \\
15-18 \text { vs. } \\
30-36 \text { sect. } \\
P \text { values }(\mathrm{n}=10)\end{array}$} \\
\hline & & $15-18 \mathrm{sec}$ & $30-36 \mathrm{sec}$ & $15-18 \mathrm{sec}$ & $30-36 \mathrm{sec}$ & \\
\hline \multirow[t]{3}{*}{$\begin{array}{l}\text { Change in mean arterial } \\
\text { pressure, } m m ~ H g\end{array}$} & $\begin{array}{l}\Delta \text { Max } \\
\text { (time to } \\
\Delta \text { Max) }\end{array}$ & $\begin{array}{c}+38.7^{*} \\
9.1 \\
(10.4)^{*} \\
(2.0)\end{array}$ & $\begin{array}{c}+57.5^{*} \\
9.9 \\
(30.3)^{*} \\
(5.1)\end{array}$ & $\begin{array}{c}+47.2^{*} \\
5.9 \\
(10.6)^{*} \\
(1.4)\end{array}$ & $\begin{array}{c}+58.8^{*} \\
7.4 \\
(20.0)^{*} \\
(4.0)\end{array}$ & $\begin{array}{l}<0.05 \\
<0.05\end{array}$ \\
\hline & $1^{\prime}$ & $\begin{array}{r}+2.8 \\
6.4\end{array}$ & $\begin{array}{c}+24.7^{*} \\
5.2\end{array}$ & $\begin{array}{c}+20.0^{*} \\
5.4\end{array}$ & $\begin{array}{r}+42.1^{*} \\
8.2^{\prime}\end{array}$ & $<0.01$ \\
\hline & $5^{\prime}$ & $\begin{array}{r}+1.2 \\
6.4\end{array}$ & $\begin{array}{r}-1.3 \\
3.7\end{array}$ & $\begin{array}{r}+1.7 \\
5.6\end{array}$ & $\begin{array}{r}+3.1 \\
1.9\end{array}$ & $>0.05$ \\
\hline \multirow[t]{3}{*}{$\begin{array}{l}\text { Change in heart rate, } \\
\text { beats/min }\end{array}$} & $\begin{array}{l}\Delta \text { Max } \\
\text { (time to } \\
\Delta \text { Max) }\end{array}$ & $\begin{array}{c}-44.8 \\
25.7 \\
(11.7)^{*} \\
(2.5)\end{array}$ & $\begin{array}{c}-78.0^{*} \\
11.4 \\
(14.2)^{*} \\
(2.5)\end{array}$ & $\begin{array}{c}+55.9^{*} \\
10.6 \\
(10.0)^{*} \\
(1.4)\end{array}$ & $\begin{array}{l}+49.4^{*} \\
9.2 \\
(15.6)^{*} \\
(2.1)\end{array}$ & $\begin{array}{l}>0.05 \\
>0.05\end{array}$ \\
\hline & $1^{\prime}$ & $\begin{array}{r}-19.8 \\
11.9\end{array}$ & $\begin{array}{r}-14.7 \\
14.6\end{array}$ & $\begin{array}{r}+7.6 \\
9.7\end{array}$ & $\begin{array}{c}+23.3^{*} \\
6.5\end{array}$ & $<0.05$ \\
\hline & $5^{\prime}$ & $\begin{array}{l}-14.2^{*} \\
6.6\end{array}$ & $\begin{array}{c}-24.2^{*} \\
6.3\end{array}$ & $\begin{array}{r}-4.1 \\
7.2\end{array}$ & $\begin{array}{r}+2.8 \\
4.6\end{array}$ & $>0.05$ \\
\hline \multirow[t]{2}{*}{$\begin{array}{l}\text { Change in cardiac index, } \\
m l / k g \text { per min }\end{array}$} & $1^{\prime}$ & $\begin{array}{r}+21^{*} \\
7.5\end{array}$ & $\begin{array}{r}+32^{*} \\
15.8\end{array}$ & $\begin{aligned}+45^{*} \\
11.8\end{aligned}$ & $\begin{array}{r}+56^{*} \\
10.4\end{array}$ & $<0.05$ \\
\hline & $5^{\prime}$ & $\begin{array}{r}-14^{*} \\
6.1\end{array}$ & $\begin{array}{r}-14^{*} \\
6.3\end{array}$ & $\begin{array}{l}-3 \\
6.6\end{array}$ & $\begin{array}{l}-2 \\
4.8\end{array}$ & $>0.05$ \\
\hline \multirow[t]{2}{*}{$\begin{array}{l}\text { Change in stroke work, } \\
m l \times m m ~ H g\end{array}$} & $1^{\prime}$ & $\begin{array}{r}+667^{*} \\
207.8\end{array}$ & $\begin{array}{r}+1405^{*} \\
325.1\end{array}$ & $\begin{array}{r}+812^{*} \\
171.4\end{array}$ & $\begin{array}{r}+1047^{*} \\
110.2\end{array}$ & $<0.01$ \\
\hline & $5^{\prime}$ & $\begin{array}{l}-49 \\
236.5\end{array}$ & $\begin{array}{l}+92 \\
168.8\end{array}$ & $\begin{array}{l}+7 \\
140.6\end{array}$ & $\begin{array}{l}-28 \\
47.6\end{array}$ & $>0.05$ \\
\hline
\end{tabular}

Entries represent averages and standard errors. $\Delta$ Max refers to maximal changes observed after conversion; the time between conversion and $\Delta$ Max is indicated in parentheses in seconds under $\Delta$ Max.

* Indicates that the average responses are statistically significant.

¥ Refers to the statistical significance of the differences between responses observed after episodes of fibrillation lasting 15-18 sec and responses observed after episodes of fibrillation lasting 30-36 sec in the same animals. The number of countershocks necessary for conversion was not always the same after the short and long episodes of fibrillation; since countershock alone may have hemodynamic effects our statistical comparison of the effect of duration of fibrillation was made on results from 10 experiments in which the same number of countershocks was necessary for conversion after the long and short periods of fibrillation. In 9 of these 10 dogs a single countershock was needed for conversion and in one dog two countershocks were necessary. These 10 experiments included three dogs that were untreated and seven that had had atropine and bilateral vagotomy. 
TABLE V

Averages ( $(x)$ and Standard Errors (SE) of Levels of pH, Blood Gases, and Lactate in Arterial Blood Samples Obtained before and at 1 and 5-min. Intervals after Converșion from Episodes of Ventricular Fibrillation Lasting 30-36 sec

\begin{tabular}{|c|c|c|c|c|c|c|c|c|c|c|c|c|}
\hline & \multicolumn{3}{|c|}{$\mathrm{pH}$} & \multicolumn{3}{|c|}{$\mathrm{pO}_{2}$} & \multicolumn{3}{|c|}{$\mathrm{pCO}_{2}$} & \multicolumn{3}{|c|}{ Lactate } \\
\hline & \multirow[b]{2}{*}{ Before } & \multicolumn{2}{|c|}{ After } & \multirow[b]{2}{*}{ Before } & \multicolumn{2}{|c|}{ After } & \multirow[b]{2}{*}{ Before } & \multicolumn{2}{|c|}{ After } & \multirow[b]{2}{*}{ Before } & \multicolumn{2}{|c|}{ After } \\
\hline & & $1^{\prime}$ & $5^{\prime}$ & & $1^{\prime}$ & $5^{\prime}$ & & $1^{\prime}$ & $5^{\prime}$ & & $1^{\prime}$ & $5^{\prime}$ \\
\hline & $U$ & $U$ & $U$ & & $m g H g$ & & & $\mathrm{Hg}$ & & & $\mathrm{s} / 100 \mathrm{ml}$ & \\
\hline $\bar{x}$ & 7.396 & $7.360^{*}$ & 7.399 & 152 & 146 & 163 & 30.2 & $34.5^{*}$ & 30.7 & 170 & 163 & 171 \\
\hline SE & 0.010 & 0.010 & 0.010 & , 7.3 & 7.9 & 6.5 & 1.1 & 1.4 & 1.5 & 25.4 & 24.6 & 26.1 \\
\hline nf & 16 & 16 & 11 & 16 & 16 & 11 & 16 & 14 & 11 & 11 & 12 & 11 \\
\hline
\end{tabular}

* Identifies the average values obtained after conversion that were significantly different from those obtained before fibrillation. $\ddagger$ Entries represent data from a total of 16 dogs; seven dogs had bilateral vagotomy and atropine and the other nine dogs had no such interventions. The values of the two groups were pooled because there were no differences between their responses.

bility relates to the lower levels of left ventricular enddiastolic pressure after phenoxybenzamine. Although a change in end-diastolic presure does not account for the inotropic response to defibrillation, the adrenergic stimulus caused by defibrillation may have evoked a smaller inotropic response at the lower levels of end-

TABLE VI

Effects of Countershock without Ventricular Fibrillation

\begin{tabular}{|c|c|c|c|c|c|}
\hline Response & & $\begin{array}{l}\text { Before atropine } \\
\text { and vagotomy: } \\
\quad \mathbf{n}=\mathbf{7}\end{array}$ & $\begin{array}{l}P \text { values } \\
\text { (d.f. 11) }\end{array}$ & $\begin{array}{c}\text { After atropine } \\
\text { and vagotomy: } \\
n=7\end{array}$ & $\begin{array}{l}P \text { values } \\
\text { (d.f. 14) }\end{array}$ \\
\hline \multirow[t]{3}{*}{$\begin{array}{l}\text { Change in mean arterial } \\
\text { pressure, } m m H g\end{array}$} & $\begin{array}{l}\Delta \text { Max } \\
\text { (time to } \\
\Delta \mathrm{Max} \text { ) }\end{array}$ & $\begin{array}{c}-5.4 \\
33.7 \\
(8.6) \\
(1.9)\end{array}$ & $\begin{array}{l}<0.01 \\
<0.01\end{array}$ & $\begin{array}{c}+27.1^{*} \\
4.8 \\
(7.9)^{*} \\
(0.9)\end{array}$ & $\begin{array}{l}<0.01 \\
<0.05\end{array}$ \\
\hline & $1^{\prime}$ & $\begin{array}{r}-0.1 \\
6.8\end{array}$ & $<0.05$ & $\begin{array}{r}+3.9 \\
2.8\end{array}$ & $<0.01$ \\
\hline & $5^{\prime}$ & $\begin{array}{c}-14.3^{*} \\
2.8\end{array}$ & $<0.05$ & $\begin{array}{c}-11.7^{*} \\
3.5\end{array}$ & $<0.01$ \\
\hline \multirow[t]{3}{*}{$\begin{array}{l}\text { Change in heart rate, } \\
\text { beats/min }\end{array}$} & $\begin{array}{l}\Delta \operatorname{Max} \\
\text { (time' to } \\
\Delta \text { Max) }\end{array}$ & $\begin{array}{r}+20.7 \\
26.1 \\
(6.4) \\
(0.8)\end{array}$ & $\begin{array}{l}<0.01 \\
<0.05\end{array}$ & $\begin{array}{c}+47.9^{*} \\
10.1 \\
(5.7)^{*} \\
(0.7)\end{array}$ & $\begin{array}{l}>0.05 \\
<0.01\end{array}$ \\
\hline & $1^{\prime}$ & $\begin{array}{r}-10.7 \\
11.8\end{array}$ & $>0.05$ & $\begin{array}{r}+2.1 \\
3.5\end{array}$ & $<0.05$ \\
\hline & $5^{\prime}$ & $\begin{array}{r}-4.3 \\
6.2\end{array}$ & $<0.05$ & $\begin{array}{c}-4.3^{*} \\
1.6\end{array}$ & $>0.05$ \\
\hline \multirow[t]{2}{*}{$\begin{array}{l}\text { Change in cardiac index, } \\
m l / k g \text { per min }\end{array}$} & $1^{\prime}$ & $\begin{array}{r}-7.1 \\
5.8\end{array}$ & $<0.05$ & $\begin{array}{c}+17.3^{*} \\
5.8\end{array}$ & $<0.05$ \\
\hline & $5^{\prime}$ & $\begin{array}{r}-11.4^{*} \\
5.7\end{array}$ & $>0.05$ & $\begin{array}{r}+7.4 \\
4.3\end{array}$ & $>0.05$ \\
\hline
\end{tabular}

See footnote to Table IV.

- Indicates reponses which are statistically significant.

$\ddagger P$ values were obtained by "group comparison" of data shown in this table with corresponding data in Table IV which represent responses observed when countershock was administered for conversion from episodes of VF lasting 30-36 sec. The effect of countershock before atropine and vagotomy ( $n=7$, first column in this table) was compared to the effect of defibrillation before atropine and vagotomy ( $n=6$, second column in Table IV). Similarly results obtained with countershock after atropine and vagotomy $(n=7$, second column in this table) were compared to the results with defibrillation after atropine and vagotomy $(n=9$, fourth column, Table IV). 
TABLE VII

Effect of Propranolol on Responses to Ventricular Defibrillation and to Intravenous Isoproterenol in Dogs That Had Atropine and Bilateral Vagotomy

\begin{tabular}{|c|c|c|c|c|c|c|c|c|c|c|c|c|c|}
\hline \multirow[b]{3}{*}{ Exp. No. } & \multicolumn{9}{|c|}{ Ventricular fibrillation } & & & & \\
\hline & \multicolumn{5}{|c|}{$15-17 \mathrm{sec}$} & \multicolumn{4}{|c|}{$30-36 \mathrm{sec}$} & \multicolumn{4}{|c|}{ Isoproterenol, $\mu \mathrm{g} / \mathrm{kg}$ per min } \\
\hline & & c & $\operatorname{Max}$ & $1^{\prime}$ & $5^{\prime}$ & $\mathrm{C}$ & $\operatorname{Max}$ & $1^{\prime}$ & $5^{\prime}$ & C & 0.125 & 0.25 & 0.50 \\
\hline \multicolumn{14}{|c|}{ Mean arterial blood pressure, $\mathrm{mm} \mathrm{Hg}$} \\
\hline \multirow[t]{2}{*}{20} & B & 142 & 205 & 165 & 135 & 150 & 205 & 200 & 150 & - & - & - & - \\
\hline & A & 145 & 165 & 162 & 142 & - & - & - & - & 148 & - & 158 & - \\
\hline \multirow[t]{2}{*}{21} & B & 110 & 170 & 150 & 110 & 140 & 190 & 185 & 140 & 105 & 80 & 70 & 70 \\
\hline & A & 90 & 110 & 90 & 85 & 65 & 130 & 95 & 60 & 102 & 120 & 123 & 115 \\
\hline \multirow[t]{2}{*}{22} & B & - & - & - & - & 110 & 150 & 130 & 100 & 110 & 103 & 98 & 72 \\
\hline & A & 90 & 125 & 115 & 95 & 90 & 140 & 140 & 80 & 78 & 80 & 88 & 98 \\
\hline \multirow[t]{2}{*}{23} & B & 148 & 190 & 170 & 140 & 142 & 200 & 188 & 143 & 138 & 145 & 123 & 115 \\
\hline & A & 128 & 170 & 165 & 140 & 133 & 165 & 162 & 128 & 112 & 123 & 138 & 140 \\
\hline \multirow[t]{2}{*}{24} & $\mathrm{~B}$ & 180 & 240 & 225 & 200 & 150 & 205 & 180 & 150 & 145 & 155 & 155 & 140 \\
\hline & A & 150 & 200 & 200 & 170 & 152 & 167 & 165 & 145 & 145 & 160 & 163 & 168 \\
\hline \multirow{2}{*}{25} & B & 155 & 185 & 155 & 135 & 135 & 203 & 170 & 145 & 134 & 133 & 140 & 140 \\
\hline & A & 145 & 163 & 140 & 148 & 145 & 170 & 170 & 153 & 140 & 140 & 140 & 140 \\
\hline \multirow[t]{2}{*}{ Means } & B & 147 & $198^{*}$ & $173^{*}$ & 144 & 137 & $192^{*}$ & $175^{*}$ & 138 & 126 & 123 & 117 & $107^{*}$ \\
\hline & $\mathrm{A}$ & $124 \ddagger$ & $155^{*} \ddagger$ & $145^{*} \ddagger$ & 130 & 117 & $154^{*} \ddagger$ & $146^{*} \ddagger$ & 113 & 121 & $125^{*}$ & $135^{*}$ & $134^{*}$ \\
\hline \multicolumn{14}{|c|}{ Heart rate, beats/min } \\
\hline \multirow[t]{2}{*}{20} & B & 175 & 235 & 205 & 170 & 200 & 240 & 230 & 190 & - & - & - & - \\
\hline & A & 150 & 150 & 150 & 150 & - & - & - & - & 140 & - & 160 & - \\
\hline \multirow[t]{2}{*}{21} & B & 200 & 250 & 220 & 200 & 200 & 250 & 230 & 210 & 215 & 260 & 270 & 290 \\
\hline & $\mathrm{A}$ & 170 & 150 & 150 & 170 & 165 & 160 & 160 & 175 & 175 & 185 & 190 & 222 \\
\hline \multirow[t]{2}{*}{22} & B & - & - & - & - & 210 & 230 & 200 & 210 & 210 & 225 & 235 & 240 \\
\hline & A & 155 & 150 & 150 & 150 & 150 & 130 & 150 & 155 & 150 & 150 & 150 & 150 \\
\hline \multirow[t]{2}{*}{23} & B & 175 & 250 & 170 & 185 & 180 & 260 & 200 & 200 & 200 & 210 & 220 & 225 \\
\hline & A & 145 & 145 & 140 & 145 & 145 & 140 & 145 & 145 & 138 & 140 & 140 & 145 \\
\hline \multirow[t]{2}{*}{24} & B & 200 & 260 & 250 & 215 & 200 & 260 & 245 & 195 & 200 & 230 & 250 & 270 \\
\hline & A & 175 & 180 & 180 & 170 & 170 & 185 & 180 & 180 & 175 & 175 & 180 & 190 \\
\hline \multirow[t]{2}{*}{25} & B & 150 & 220 & 155 & 160 & 160 & 230 & 200 & 160 & 180 & 190 & 200 & 210 \\
\hline & A & 135 & 150 & 140 & 130 & 135 & 130 & 150 & 140 & 130 & 130 & 135 & 135 \\
\hline \multirow[t]{2}{*}{ Means } & B & 180 & $243^{*}$ & 200 & 186 & 192 & $245^{*}$ & $217^{*}$ & 194 & 201 & $223^{*}$ & $235^{*}$ & $247^{*}$ \\
\hline & A & $155 \ddagger$ & $154 \ddagger$ & $153 \ddagger$ & $152 \ddagger$ & $153 \ddagger$ & $149 \ddagger$ & $157 \ddagger$ & $159 \ddagger$ & $151 \ddagger$ & $156 \ddagger$ & $159 \ddagger$ & $168 \ddagger$ \\
\hline Cardiac in & $\mathrm{ml} /$ & $g$ per $n$ & & & & & & & & & & & \\
\hline 20 & B & 140 & - & 168 & 141 & .133 & - & 195 & 140 & - & - & - & - \\
\hline & A & 59 & - & 70 & 58 & - & - & - & - & 63 & - & 78 & - \\
\hline 21 & B & 151 & - & 155 & 126 & 134 & - & 148 & 122 & 110 & 135 & 157 & 192 \\
\hline & A & 40 & - & 44 & 40 & 27 & - & 36 & 28 & 40 & 49 & 65 & 77 \\
\hline 22 & B & - & - & - & - & 85 & - & 138 & 76 & 82 & 94 & 106 & 112 \\
\hline & A & 50 & - & 57 & 51 & 42 & - & 61 & 44 & 46 & 46 & 47 & 54 \\
\hline 23 & B & 111 & - & 132 & 100 & 103 & - & 153 & 96 & 93 & 111 & 120 & 130 \\
\hline & A & 57 & - & 45 & 51 & 49 & - & 46 & 48 & 54 & 57 & 64 & 73 \\
\hline
\end{tabular}


TABLE VII-(Continued)

\begin{tabular}{|c|c|c|c|c|c|c|c|c|c|c|c|c|c|}
\hline \multirow[b]{3}{*}{ Exp. No. } & \multicolumn{9}{|c|}{ Ventricular fibrillation } & & & & \\
\hline & \multicolumn{5}{|c|}{$15-17 \mathrm{sec}$} & \multicolumn{4}{|c|}{$30-36 \mathrm{sec}$} & \multicolumn{4}{|c|}{ Isoproterenol, $\mu \mathrm{g} / \mathrm{kg}$ per min } \\
\hline & & $\mathrm{C}$ & $\operatorname{Max}$ & $1^{\prime}$ & $5^{\prime}$ & C & $\operatorname{Max}$ & $1^{\prime}$ & $5^{\prime}$ & C & 0.125 & 0.25 & 0.50 \\
\hline \multirow[t]{2}{*}{24} & B & 210 & 一 & 330 & 240 & 160 & - & 239 & 160 & 129 & 179 & 184 & 202 \\
\hline & A & 69 & 一 & 63 & 71 & 60 & - & 57 & 60 & 82 & 83 & 87 & 98 \\
\hline \multirow[t]{2}{*}{25} & B & 174 & - & 252 & 160 & 156 & - & 262 & 136 & 136 & 156 & 234 & 217 \\
\hline & A & 81 & - & 96 & 76 & 73 & - & 111 & 76 & 81 & 85 & 86 & 105 \\
\hline \multirow[t]{2}{*}{ Means } & B & 157 & - & $207^{*}$ & 153 & 128 & - & $189^{*}$ & 122 & 110 & $135^{*}$ & $160^{*}$ & $171^{*}$ \\
\hline & A & $59 \ddagger$ & - & $62 \ddagger$ & $58 \ddagger$ & $50 \ddagger$ & - & $62 \ddagger$ & $51 \ddagger$ & $61 \ddagger$ & $64 \ddagger$ & $71^{*} \ddagger$ & $81^{*} \ddagger$ \\
\hline
\end{tabular}

See footnote to Table I. C refers to observations made before ventricular fibrillation or before infusion of isoproterenol. B and A refer to observations made before and after propranolol respectively.

* Indicates that the mean values were significantly different from corresponding control values (C).

$\ddagger$ Indicates that the mean values observed after propranolol (A) were significantly different from corresponding values observed before the blocker (B).

diastolic pressure observed after phenoxybenzamine. This is suggested from the appearance of left ventricular function curves which are not only shifted to the left but are also steeper during an adrenergic stimulus (20).

There are three reasons why we think that the hemodynamic responses to defibrillation are not simply a reflection of the cardiac effects of countershock. The first is that the administration of countershock alone without ventricular fibrillation caused minimal and inconsistent hemodynamic changes before atropine and vagotomy. After cholinergic blockade, countershock caused significant increases in arterial pressure and heart rate but these were transient lasting less than 30 sec. On the other hand, responses after defibrillation

TABLE VIII

Effect of Phenoxybenzamine on Responses to Ventricular Defibrillation and to Intravenous Norepinephrine in Dogs That Had Atropine and Bilateral Vagotomy

\begin{tabular}{|c|c|c|c|c|c|c|c|c|c|c|c|c|c|c|}
\hline \multirow[b]{3}{*}{ Exp. No. } & \multicolumn{6}{|c|}{ Ventricular fibrillation : $30-39 \mathrm{sec}$} & \multirow{2}{*}{\multicolumn{8}{|c|}{ Norepinephrine, $\mu g / k g$ per min }} \\
\hline & & C & $\operatorname{Max}$ & $1^{\prime}$ & c & \multirow[b]{2}{*}{ index } & & & & & & & & \\
\hline & & \multicolumn{3}{|c|}{$\begin{array}{l}\text { Mean arterial blood } \\
\text { pressure }\end{array}$} & Cardiac index & & \multicolumn{5}{|c|}{ Mean arterial blood pressure } & \multicolumn{3}{|c|}{ Cardiac index } \\
\hline & & \multicolumn{3}{|c|}{$m m \mathrm{Hg}$} & \multicolumn{2}{|c|}{$m l / k g$ per min } & \multicolumn{4}{|c|}{$m m \mathrm{Hg}$} & & \multicolumn{2}{|c|}{$\mathrm{ml} / \mathrm{kg}$ per min } & \\
\hline 34 & $\begin{array}{l}\text { B } \\
\text { A }\end{array}$ & $\begin{array}{l}145 \\
135\end{array}$ & $\begin{array}{l}195 \\
140\end{array}$ & $\begin{array}{l}170 \\
125\end{array}$ & $\begin{array}{l}82 \\
76\end{array}$ & $\begin{array}{l}86 \\
80\end{array}$ & & & & & & & & \\
\hline 35 & $\begin{array}{l}\text { B } \\
\text { A }\end{array}$ & $\begin{array}{r}150 \\
90\end{array}$ & $\begin{array}{r}190 \\
93\end{array}$ & $\begin{array}{r}190 \\
92\end{array}$ & $\begin{array}{r}138 \\
71\end{array}$ & $\begin{array}{r}183 \\
93\end{array}$ & & & & & & & & \\
\hline 36 & $\begin{array}{l}\text { B } \\
\text { A }\end{array}$ & $\begin{array}{r}150 \\
55\end{array}$ & $\begin{array}{r}180 \\
65\end{array}$ & $\begin{array}{r}155 \\
60\end{array}$ & $\begin{array}{l}120 \\
131\end{array}$ & $\begin{array}{l}162 \\
136\end{array}$ & & & & & & & & \\
\hline 37 & $\begin{array}{l}\text { B } \\
\text { A }\end{array}$ & $\begin{array}{r}145 \\
90\end{array}$ & $\begin{array}{r}200 \\
87\end{array}$ & $\begin{array}{r}170 \\
77\end{array}$ & $\begin{array}{l}161 \\
120\end{array}$ & $\begin{array}{l}235 \\
160\end{array}$ & $\begin{array}{l}148 \\
100\end{array}$ & $\begin{array}{l}165 \\
102\end{array}$ & $\begin{array}{l}180 \\
100\end{array}$ & $\begin{array}{r}200 \\
95\end{array}$ & $\begin{array}{l}147 \\
115\end{array}$ & $\begin{array}{l}155 \\
132\end{array}$ & $\begin{array}{l}159 \\
136\end{array}$ & $\begin{array}{l}197 \\
144\end{array}$ \\
\hline 38 & $\begin{array}{l}\text { B } \\
\text { A }\end{array}$ & $\begin{array}{r}135 \\
90\end{array}$ & $\begin{array}{r}240 \\
97\end{array}$ & $\begin{array}{r}175 \\
95\end{array}$ & $\begin{array}{l}154 \\
145\end{array}$ & $\begin{array}{l}162 \\
167\end{array}$ & $\begin{array}{l}137 \\
103\end{array}$ & $\begin{array}{l}155 \\
100\end{array}$ & $\begin{array}{l}210 \\
108\end{array}$ & $\begin{array}{l}210 \\
103\end{array}$ & $\begin{array}{l}141 \\
129\end{array}$ & $\begin{array}{l}153 \\
151\end{array}$ & $\begin{array}{l}202 \\
165\end{array}$ & $\begin{array}{l}231 \\
213\end{array}$ \\
\hline Means & $\begin{array}{l}\mathrm{B} \\
\mathrm{A}\end{array}$ & $\begin{array}{c}145 \\
92 \ddagger\end{array}$ & $\begin{array}{r}201^{*} \\
96 \ddagger\end{array}$ & $\begin{array}{r}172^{*} \\
90 \ddagger\end{array}$ & $\begin{array}{l}131 \\
108\end{array}$ & $\begin{array}{l}166^{*} \\
127^{*}\end{array}$ & & & & & & & & \\
\hline
\end{tabular}

See footnote to Tabel VII. $\mathrm{C}$ refers to observations made before ventricular fibrillation or before norepinephrine. Observations were made after conversion from episodes of fibrillation lasting 30-39 sec. B and A refer to data obtained before and after phenoxybenzamine respectively. 
lasted from 1 to $10 \mathrm{~min}$. The increase in cardiac output observed at $1 \mathrm{~min}$ after countershock amounted to only $30 \%$ of the corresponding increase after defibrillation. We did observe, also, a reduction in arterial pressure and cardiac output $5 \mathrm{~min}$ after countershock. This was not seen after defibrillation. The transitory nature of the increases in pressure, heart rate, and cardiac ouput observed with countershock only, supports the findings of Cobb et al. (4) who reported positive inotropic responses lasting $20 \mathrm{sec}$ or less after the shock and the observations of Childers et al. (10) who indicated that the maximal electrocardiographic changes occur 5$10 \mathrm{sec}$ after shock. A second reason why we believe that the effects of defibrillation are not simply those of countershock is the close correlation between the duration of fibrillation and the responses. A third reason is that in the occasional situation in which spontaneous conversion took place before countershock a bradycardia and an increase in arterial pressure were noted (Fig. 6).

Simultaneous activation of parasympathetic and sympathetic efferent pathways to the cardiovascular system which we have observed with defibrillation has been described also in animals and in man as part of an oxygen-conserving reflex with diving $(21,22)$. The bradycardia would tend to reduce myocardial oxygen requirements and the sympathetic drive would increase stroke volume and redistribute peripheral blood flow toward more vital organs. In our experiments, however, the parasympathetic component appeared to favor the recurrence of fibrillation. On the other hand, the adrenergic component was important for defibrillation since depletion of endogenous catecholamines with reserpine resulted in failure of recovery in five of six dogs. In all these animals complete A-V block occurred immediately after defibrillation and was maintained for 1-2 min after which the restoration of $\mathrm{A}-\mathrm{V}$ transmission and effective circulation was associated with a progressive decline in arterial pressure except in one dog. This effect of reserpine on $A-V$ transmission is in accord with findings of Hoffman and Singer (23) who emphasized that the only obvious differences in timing of various cardiac electrical events between control animals and those given reserpine $0.3 \mathrm{mg} / \mathrm{kg}$ per day for 3 days were the presence of $2: 1 \mathrm{~A}-\mathrm{V}$ block and the slowed conduction of the $\mathrm{A}-\mathrm{V}$ node. Even after the administration of atropine the only consistent effect of reserpine was a slight increase in refractoriness of $\mathrm{A}-\mathrm{V}$ node. These responses may represent direct or indirect effects of depletion of catecholamines but they may also result from a direct action of reserpine on cardiac cell membrane (24). It might be noted in this regard that the effect of propranolol on the responses to defibrillation differed from that of reserpine. Propranolol simply prevented the positive inotropic and chronotropic components of the response to defibrillation but all the animals treated with the beta blocker recovered. The beneficial role that endogenous catecholamines seem to have in ventricular defibrillation might explain the difficulty encountered clinically in attempting to resuscitate patients with chronic heart disease who may have depletion of cardiac catecholamines (25).

The observations reported here provide no information on the mechanism of activation of the cholinergic and adrenergic pathways during defibrillation. Afferent impulses may originate from the coronary vessels, from myocardial stretch receptors, from baroreceptors, or from chemoreceptors. The response may result from cerebral ischemia. The data indicate, however, that afferent impulses mediated through the vagi are not essential for the positive inotropic and chronotropic effects or for the pressor responses to ventricular defibrillation. The small changes in blood $\mathrm{pH}$ and the lack of a significant change in blood levels of lactate would suggest that the contribution of metabolic acidosis or other metabolic factors resulting from the brief periods of peripheral ischemia is also minimal.

\section{ACKNOWLEDGMENTS}

We gratefully acknowledge the technical assistance of Mrs. Siska McGreevy.

This study was supported by research grants from the American and Iowa Heart Associations, the U. S. Public Health Service (HE-09835 and HE-02644), and by a Research Career Program Award HE-K3-17013 (Dr. Abboud) and a Clinical Cardiology Traineeship 5T-12HE-05729 (Dr. Pansegrau) from the U. S. Public Health Service.

\section{REFERENCES}

1. Pansegrau, D. G., F. M. Abboud, and L. E. January. 1968. Autonomic mechanisms associated with conversion of ventricular fibrillation. J. Lab. Clin. Med. 72: 1001. (Abstr.)

2. Pansegrau, D. G., and F. M. Abboud. 1968. Hemodynamic effects of ventricular defibrillation. Clin. Res. 16: 436. (Abstr.)

3. Nelemans, F. A. 1951. Liberation of sympathin and acetylcholine by faradic stimulation of the frog's heart. Acta Physiol. Pharmacol. Neer. 2: 51.

4. Cobb, F. R., A. G. Wallace, and G. S. Wagner. 1968. Cardiac inotropic and coronary vascular responses to countershock. Evidence for excitation of intracardiac nerves. Circ. Res. 23: 731.

5. Whitacre, T. S., J. P. Long, and W. J. Whalen. 1965. Transmural and vagal nerve stimulation of the right atrium of the cat. Amer. J. Physiol. 210: 557.

6. Furchgott, R. F., T. De Gubareff, and A. Grossman. 1959. Release of autonomic mediators in cardiac tissue by suprathreshold stimulation. Science (Washington). 129: 328

7. Whalen, W. J., N. Fishman, and R. Erickson. 1958. Nature of the potentiating substance in cardiac muscle. Amer. J. Physiol. 194: 573. 
8. Blinks, J. R. 1966. Field stimulation as a means of effecting the graded release of autonomic transmitters in isolated heart muscle. J. Pharmacol. Exp. Ther. 151: 221.

9. Vincenzi, F. F., and T. C. West. 1963. Release of autonomic mediators in cardiac tissue by direct subthreshold electrical stimulation. J. Pharmacol. Exp. Ther. 141: 185.

10. Childers, R. W., D. Rothbaum, and M. F. Arnsdorf. 1967. Effect of direct-current shock on the electrical properties of the heart. Circulation. 36 (Suppl. 2) : 85. (Abstr.)

11. Capapas, L. R., and R. H. Martin. 1968. Hemodynamic effects of synchronized precordial shock in the dog. Circulation. 37 (Suppl. 6) : 51. (Abstr.)

12. Lown, B., R. Kleiger, and J. Williams. 1965. Cardioversion and digitalis drugs: changed threshold to electrical shock in digitalized animals. Circ. Res. 17: 519.

13. Ten Eick, R. E., S. R. Wyte, S. M. Ross , and B. F. Hoffman. 1967. Postcountershock arrhythmias in untreated and digitalized dogs. Circ. Res. 21: 375 .

14. Lown, B., J. Neuman, R. Amarasingham, and B. V. Berkovits. 1963. Comparison of alternating current with direct current electroshock across the closed chest. Amer. J. Cardiol. 10: 223.

15. Main, F. B., E. Aberdeen, and F. L. A. Gerbode. 1963. Comparison of ventricular function subsequent to multiple defibrillations utilizing the alternating current and the direct current defibrillators. Surg. Forum Proc. Forum Fundam. Surg. Probl. Clin. Congr. Amer. Coll. Surg. 14: 258.

16. Marbach, E. P., and M. H. Weil. 1967. Rapid enzymatic measurement of blood lactate and pyruvate. Use and significance of metaphosphoric acid as a common precipitant. Clin. Chem. 13: 314.

17. Hamilton, W. F., I. W. Moore, J. M. Kinsman, and R. G. Spruling. 1932. Studies on the circulation. IV. Fur- ther analysis of the injection method, and of changes in hemodynamics under physiological and pathological conditions. Amer. J. Physiol. 99: 534.

18. Dixon, W. J., and F. J. Massey. 1966. Introduction to statistical analysis. McGraw-Hill Book Company, New York. 286.

19. Han, J., J. DeTreglia, D. Millet, and G. K. Moe. 1966. Incidence of ectopic beats as a function of basic rate in the ventricle. Amer. Heart J. 72: 632 .

20. Sarnoff, J. J., and J. H. Mitchell. 1962. Control of the function of the heart. In Handbook of Physiology, Section 2. W. F. Hamilton and P. Dow, editors. The American Physiological Society, Washington, D. C. 490.

21. Wolf, S., R. A. Schneider, and M. E. Groover. 1965. Further studies on the circulatory and metabolic alterations of the oxygen-conserving (diving) reflex in man. Trans. Ass. Amer. Physicians, Philadelphia. 78: 242.

22. Heistad, D. D., F. M. Abboud, and J. W. Eckstein. 1968. Vasoconstrictor response to simulated diving in man. J. Appl. Physiol. 25: 542.

23. Hoffman, B. F., and D. H. Singer. 1967. Appraisal of the effects of catecholamines on cardiac electrical activity. In New Adrenergic Blocking Drugs: Their Pharmacological, Biochemical and Clinical Actions. N. C. Moran, editor. Ann. N. Y. Acad. Sci. 139: 914.

24. Toda, N. 1960. Effects of adrenaline, noradrenaline, and reserpine on the transmembrane potentials in both pacemaker and non-pacemaker fibers of the rabbit atrium. Jap. J. Pharmacol. 10: 78.

25. Chidsey, C. A., E. Braunwald, and A. G. Morrow. 1965. Catecholamine excretion and cardiac stores of norepinephrine in congestive heart failure. Amer. J. Med. 39: 442 